\title{
FORMAT PEMBELAJARAN PILIHAN GURU UNTUK ANAK KEMBALI SEKOLAH SELAMA PANDEMI COVID-19
}

\author{
Ali Audah \\ Sekolah Tinggi Agama Islam At-Tahdzib Jombang \\ email : aliaudah79@gmail.com
}

\begin{abstract}
In the midst of the Covid-19 pandemic, there is a need to understand teacher choices for the format of teaching children at the start of the 2020-2021 academic year. The aim of the study was to assess teacher choices in school versus virtual at home learning during the 2019-2020 school year and the factors associated with the choice. Participants were 100 samples of teachers on elementary, junior and high school in the City of Jombang. Teachers are asked to fill out an online survey about initial options for students to return to the school learning environment. The results showed that teachers on the junior and high school are more supportive of the choice of the hybrid learning format in schools and the scheduled virtual hybrid teaching and do not support the choice of face-to-face traditional learning formats in schools. Meanwhile, elementary school teachers are more supportive of traditional learning formats. Regardless of school level, concerns about child health and safety were the factors most strongly correlated with teacher preferences for in-school learning versus virtual learning at home. This data highlights the importance of plans to reopen schools that offer virtual choices and address teacher concerns about child health and safety amid the Covid-19 pandemic.
\end{abstract}

Keywords: Covid-19; online learning; teachers choice; virtual learning; child health

\section{Pendahuluan}

Word Health Organization (WHO), pada 11 Maret 2020, resmi mengumumkan wabah Covid-19 sebagai pandemi global. ${ }^{1}$ Hal ini mengakibatkan pergeseran ke pengajaran jarak jauh/ online untuk sebagian besar sekolah di seluruh negeri. Sementara sebagian besar sekolah yang pindah ke format jarak jauh/ online/ daring tidak pernah kembali ke pengajaran tatap muka selama tahun akademik 2019 hingga awal 2020, ada banyak antisipasi tentang seperti apa instruksi sekolah ketika sekolah melanjutkan untuk tahun akademik 2020 hingga 2021, terutama karena tingkat Covid-19 terus meningkat di seluruh negeri.

Surat Keputusan Bersama (SKB) Menteri Pendidikan dan Kebudayaan, Menteri Agama, Menteri Kesehatan dan Menteri dalam Negeri Republik Indonesia ${ }^{2}$ memberikan pedoman

1 WHO Director-General's opening remarks at the media briefing on COVID-19 - 11 March 2020. www.who.int. Diakses 20 November 2020.

2 SKB Nomor 01/KB/2020; Nomor 516 Tahun 2020; Nomor HK.03.01/Menkes/363/2020; Nomor 440-882 Tahun 2020 Tentang Panduan Penyelenggaraan Pembelajaran pada Tahun Ajaran 2020/2021 dan Tahun Akademik 2020/2021 di Masa Pandemi Corona Virus Disease 2019 (Covid-19). Diakses 20 November 2020. 
tentang bagaimana sekolah umum akan dilanjutkan selama tahun akademik 2020 hingga 2021. Pedoman ini digunakan oleh pejabat pendidikan di setiap provinsi untuk memberikan arahan sekolah untuk dibuka kembali. Pemerintah provinsi atas arahan, koordinasi dan protokol kesehatan yang diberikan oleh Gugus Tugas Penanggulangan Covid-19 membantu sekolah mendukung kesehatan dan kesejahteraan siswa dan staf saat sekolah buka kembali untuk tahun akademik 2019, 2020 hingga 2021. Panduan menyerukan rencana yang fleksibel dan sesuai perkembangan bagi siswa yang memperhitungkan tingkat Covid-19 di wilayah sekolah. Panduan ini juga mengakui peran penting sekolah dalam mendorong perkembangan sosial-emosional dan akademis pada anak-anak dan remaja serta memberikan keamanan dan gizi. ${ }^{3}$

Temuan penelitian menunjukkan bahwa pada pembelajaran model dalam jaringan (daring), guru dan orang tua sangat berperan dalam mendukung proses anak belajar di rumah. Kerja sama orang tua dan guru sangat penting untuk menyukseskan sistem pembelajaran daring atau online. Komunikasi orang tua dan guru dengan sikap saling percaya dan saling membantu dalam membimbing anak akan membuat anak merasa memiliki kebebasan berkreativitas guna pengembangan potensi diri, sehingga bias meningkatkan kreativitas dan mencapai keberhasilan dalam belajar lebih bermakna dan bermanfaat. ${ }^{4}$ Terlepas dari itu, tidak ada penelitian yang menyelidiki pilihan guru untuk format pengajaran anak-anak untuk awal tahun ajaran baru dan faktor-faktor yang terkait dengan pilihan ini. Menjelaskan faktor-faktor tersebut dapat membantu sekolah dan pembuat kebijakan dalam mengembangkan rencana pembukaan kembali dan memenuhi kebutuhan siswa dan keluarga. Tujuan penelitian adalah untuk menilai pilihan guru untuk pembelajaran di sekolah versus pembelajaran virtual di rumah dan faktor-faktor yang terkait dengan pilihan tersebut di antara guru dengan siswa yang terdaftar sekolah tempat guru bertugas.

\section{Pandemi Covid-19}

Peristiwa penyebaran penyakit Coronavirus disease 2019 (Covid-19) di seluruh negara di dunia disebut dengan Pandemi Covid-19. Covid-19 disebabkan oleh korona virus jenis baru yang

\footnotetext{
${ }^{3}$ American Academy of Pediatrics (2020). Covid-19 planning considerations: Guidance for school re-entry website. Itasca, IL: American Academy of Pediatrics. https://services.aap .org/en/pages/2019-novel-coronaviruscovid-19-infections/ clinical-guidance/covid-19-planning-considerations-return-to- in-person-education-in-schools/ Diakses 20 November 2020.

${ }^{4}$ Chusna, P. A., \& Utami, A. D. M. (2020). Dampak Pandemi Covid-19 terhadap Peran Orang Tua dan Guru dalam Meningkatkan Kualitas Pembelajaran Daring Anak Usia Sekolah Dasar. Premiere, 2, 1, 11 - 30.
} 
diberi nama SARS-CoV-2. ${ }^{5}$ Wabah Covid-19 pertama kali dideteksi di Kota Wuhan, Provinsi Hubei, Tiongkok pada tanggal 01 Desember 2019, dan ditetapkan sebagai pandemi oleh Organisasi Kesehatan Dunia (WHO) pada tanggal 11 Maret $2020{ }^{6}$

Virus SARS-CoV-2 diduga menyebar di antara orang-orang terutama melalui percikan pernapasan (droplet) yang dihasilkan selama batuk. ${ }^{7}$ Percikan ini juga dapat dihasilkan dari bersin dan pernapasan normal. Selain itu, virus dapat menyebar akibat menyentuh permukaan benda yang terkontaminasi dan kemudian menyentuh wajah seseorang. ${ }^{8}$ Penyakit COVID-19 paling menular saat orang yang menderitanya memiliki gejala, meskipun penyebaran mungkin saja terjadi sebelum gejala muncul. ${ }^{9}$ Periode waktu antara paparan virus dan munculnya gejala biasanya sekitar lima hari, tetapi dapat berkisar dari dua hingga empat belas hari. ${ }^{10}$ Gejala umum di antaranya demam, batuk, dan sesak napas. ${ }^{11}$ Komplikasi dapat berupa pneumonia dan penyakit pernapasan akut berat. Tidak ada vaksin atau pengobatan antivirus khusus untuk penyakit ini. Pengobatan primer yang diberikan berupa terapi simtomatik dan suportif. Langkah-langkah pencegahan yang direkomendasikan di antaranya mencuci tangan, menutup mulut saat batuk, menjaga jarak dari orang lain, serta pemantauan dan isolasi diri untuk orang yang mencurigai bahwa mereka terinfeksi. ${ }^{12}$

Upaya untuk mencegah penyebaran virus corona termasuk pembatasan perjalanan, karantina, pemberlakuan jam malam, penundaan dan pembatalan acara, serta penutupan fasilitas. Upaya ini termasuk karantina Hubei, karantina nasional di Italia dan di tempat lain di Eropa, serta pemberlakuan jam malam di Tiongkok dan Korea Selatan, ${ }^{13}$ berbagai penutupan perbatasan negara atau pembatasan penumpang yang masuk, ${ }^{14}$ penapisan di bandara

\footnotetext{
${ }^{5}$ Gorbalenya, A. E. (11 Februari 2020). Severe acute respiratory syndrome-related coronavirus - The species and its viruses, a statement of the Coronavirus Study Group. Diakses 20 November 2020.

${ }^{6}$ WHO ibid.

7 Symptoms of Novel Coronavirus (2019-nCoV). US Centers for Disease Control and Prevention. 10 February 2020. Diakses 20 November 2020.

${ }^{8}$ Q\&A on coronaviruses". World Health Organization. Diakses 20 November 2020.

${ }^{9}$ Coronavirus Disease 2019 (COVID-19). Centers for Disease Control and Prevention. 16 March 2020.

${ }^{10}$ Symptoms of Novel Coronavirus (2019-nCoV). Ibid.

${ }^{11}$ Rothan, H. A., \& Byrareddy, S. N. (February 2020). The epidemiology and pathogenesis of coronavirus disease (COVID-19) outbreak. Journal of Autoimmunity: 102433. doi:10.1016/j.jaut.2020.102433. Diakses 20 November 2020.

${ }^{12}$ Coronavirus Disease 2019 (COVID-19). Ibid.

${ }^{13}$ Marsh, S. (23 February 2020). Four cruise ship passengers test positive in UK - as it happened. The Guardian. ISSN 0261-3077. Diakses 20 November 2020.

${ }^{14}$ Nikel, D. Denmark Closes Border To All International Tourists For One Month. Forbes. Diakses 20 November 2020..
} 
dan stasiun kereta, ${ }^{15}$ serta informasi perjalanan mengenai daerah dengan transmisi lokal. ${ }^{16}$ Sekolah dan universitas telah ditutup baik secara nasional atau lokal di lebih dari 124 negara dan memengaruhi lebih dari 1,2 miliar siswa. ${ }^{17}$

\section{Pembelajaran virtual}

Menurut Pannen, ${ }^{18}$ pembelajaran virtual adalah proses pembelajaran di kelas maya yang berada dalam cyberspace melalui jaringan Internet. Penerapan pembelajaran virtual ditujukan untuk mengatasi masalah keterpisahan ruang dan waktu antara siswa dan pengajar melalui media komputer. Siswa dapat memperoleh bahan belajar yang sudah dirancang dalam paket-paket pembelajaran yang tersedia dalam situs Internet. Dengan menerapkan pembelajaran virtual, siswa dapat mempelajari bahan belajar sendiri atau jika diperlukan siswa meminta bantuan dalam bentuk interaksi yang difasilitasi oleh komputer, seperti belajar berbantuan computer (computerbased learning/CAL) atau interactive web pages, belajar berbantuan pengajar atau tutor secara synchronous (dalam titik waktu yang sama) dan asynchronous (dalam titik waktu yang berbeda), atau belajar berbantuan sumber belajar lain seperti dengan siswa lain atau pakar, e-mail, dan sebagainya. Penilaian juga dilakukan secara jarak jauh melalui komputer dan terbuka. Melalui penerapan sistem penilaian terbuka, siswa dapat mengikuti penilaian kapan saja siswa siap untuk dinilai. Dari penjelasan tersebut, dapat dicermati bahwa ciri-ciri pembelajaran yang menerapkan konsep virtual learning adalah: - adanya keterpisahan antara pendidik dan peserta didik; - sistem belajar terbuka (akses yang terbuka dan kebebasan memilih ragam sumber belajar serta alur proses belajar); serta - berbasis jaringan. Konsep virtual learning dikembangkan bukan untuk menggantikan pembelajaran tatap muka. Penggabungan pembelajaran tatap muka dengan konsep virtual learning akan memungkinkan terjadinya peningkatan kualitas pembelajaran, di samping peningkatan efektivitas dan efisiensi pendidikan. Virtual learning dikembangkan untuk menunjang pembelajaran tatap muka. Virtual learning dapat diterapkan sebagai satu-satunya proses belajar dalam pendidikan jarak jauh atau digabungkan dengan pembelajaran langsung (tatap muka di kelas). Dalam penerapan virtual learning, komponen siswa, guru, dan sumber

\footnotetext{
${ }^{15}$ Coronavirus Update: Masks And Temperature Checks In Hong Kong. Nevada Public Radio. Diakses 20 November 2020.

${ }^{16}$ Deerwester, J., \& Gilbertson, D. Coronavirus: US says 'do not travel' to Wuhan, China, as airlines issue waivers, add safeguards. USA Today. Diakses 20 November 2020.

${ }_{17}^{17}$ COVID-19 Educational Disruption and Response. UNESCO. Diakses 20 November 2020.

${ }^{18}$ Belawati, t. et al. (Ed.). Pendidikan Terbuka dan Jarak Jauh. Jakarta: Universitas Terbuka. Diakses 20 November 2020.
} 
belajar difasilitasi oleh TIK untuk mencapai tujuan belajar. Prinsip utama dalam pembelajaran virtual adalah otoritas dan kolaborasi. Otoritas dalam arti, siswa memiliki tanggung jawab untuk menentukan materi, akses terhadap sumber belajar, waktu yang dimiliki, media yang akan digunakan, serta tempat dan langkah-langkah belajar yang dilakukan untuk mencapai tujuan pembelajaran. Kolaboratif dalam arti, untuk dapat melakukan tanggung jawab tersebut siswa. ${ }^{19}$

\section{Metodologi}

Penelitian ini merupakan penelitian penjelasan (Explanatory Research), yaitu penelitian yang menjelaskan hubungan dan perbedaan antar variable sesuai dengan tujuan penelitian. Hubungan antar variabel adalah variabel pilihan guru dengan keputusan guru pada format instruksi pengajaran berdasarkan tingkat sekolah. Perbedaan antar variabel adalah perbedaan sistematis antara pilihan guru pada setiap format pengajaran berdasar tingkat sekolah.

Patisipan adalah para guru sekolah dasar (SD), sekolah menengah pertama (SMP) dan sekolah menengah atas (SMA) di Kota Jombang selama tahun akademik 2019 hingga 2020. Informasi demografis para guru tidak dikumpulkan karena survei bersifat anonim. Penelitian mengambil 100 sampel guru secara purposive, masing-masing 34 guru SD, 33 guru SMP dan 33 guru SMA.

Awal tahun ajaran baru, yaitu 1 Juli 2020, sebuah file word dokumen dikirim melalui aplikasi WhatsApp (WA-Survei) kepada guru utama siswa di sekolah-sekolah negeri dan swasta. Para guru diminta untuk mengisi survei tentang pilihan awal lingkungan belajar kembali ke sekolah bagi siswa. Guru diminta untuk mengisi survei secara terpisah untuk setiap anak dan siswa di sekolah tempat para guru bertugas. File word dokumen menjelaskan tujuan survei adalah untuk membantu perencanaan tingkat kabupaten dan bahwa tanggapan terhadap survei tidak mengikat karena guru akan diminta untuk membuat keputusan akhir tentang pilihannya bagi lingkungan belajar siswa-siswinya pada awal tahun akademik 2020 hingga 2021 nanti. Tanggapan yang dianalisis dalam penelitian diterima antara tanggal 5 sampai 15 Juli 2020.

WA-Survei meminta guru untuk menunjukkan tingkat kelas yang direncanakan bagi siswa untuk hadir selama tahun akademik 2020 hingga 2021. Guru ditanya tentang format

\footnotetext{
${ }^{19}$ Julaeha, S. Virtual Learning: Pemanfaatan Teknologi Informasi DDan Komunikasi Untuk Meningkatkan Kualitas Pembelajaran. Universitas Terbuka. file://C:/Users/12/Downloads/6868-17770-1-SM\%20(1).pdf. Diakses 20 November 2020.
} 
pengajaran: "Bagaimana Anda ingin siswa Anda memulai tahun ajaran baru?" Pilihan tanggapan adalah: "Pembelajaran tradisional tatap muka di sekolah," "Di sekolah dan pengajaran hybrid virtual yang terjadwal, "dan" Sepenuhnya hybrid virtual. "Tercatat di bawah pilihan respons bahwa, "Jadwal hybrid virtual akan dilakksanakan setengah hari atau jadwal kelas A, B, C (dan seterunya) setiap hari untuk mengurangi jumlah siswa di sekolah, jika sekolah diberi mandat untuk mengurangi jumlah anak untuk mengikuti pedoman jaga jarak sosial. "Akhirnya, guru ditanya, "Faktor manakah yang merupakan faktor "garis arsir" yang benar-benar mempengaruhi keputusan Anda? Centang semua yang berlaku. Pilihan tanggapan adalah, "Kami tidak memiliki pilihan bagi anak untuk jadwal sekolah hybrid virtual," "Menawaran kursus elektif sekolah virtual," "Partisipasi dalam ekstrakurikuler," "Saya tidak ingin anak-anak diwajibkan pakai masker," "Saya ingin anak-anak wajib pakai masker, "Saya tidak ingin persyaratan wajib jaga jarak sosial," "Saya ingin persyaratan wajib jarak sosial," dan "'Lainnya" . "Untuk tujuan penelitian, analisis isi dilakukan pada tanggapan lainnya. Tema utama masalah kesehatan/ keselamatan anak muncul dari analisis isi. Secara khusus, guru yang tanggapannya termasuk dalam tema ini menunjukkan kekhawatiran tentang anak-anakyang tertular Covid-19 di lingkungan sekolah.

Analisis statistik dilakukan dengan menggunakan SPSS. Frekuensi dihitung untuk menentukan persentase siswa di setiap tingkat sekolah (SD, SMP dan SMA) dan persentase guru yang mendukung setiap pilihan format pengajaran. Uji Chi-square digunakan untuk menilai apakah ada perbedaan sistematis antara pilihan guru pada setiap format pengajaran berdasar tingkat sekolah. Analisis regresi logistik polinomial digunakan untuk memeriksa hubungan multivariat antara pilihan guru pada format instruksi pengajaran berdasarkan tingkat sekolah. Analisis regresi logistik polinomial digunakan untuk memeriksa hubungan multivariat antara pilihan guru pada format instruksi dan faktor "garis arsir" yang benar-benar mempengaruhi keputusan guru (yaitu: pembelajaran tradisional tatap muka di sekolah; di sekolah dan pengajaran hybrid virtual yang terjadwal; sepenuhnya hybrid virtual; kami tidak memiliki pilihan bagi anak untuk jadwal sekolah hybrid virtual; menawaran kursus elektif sekolah virtual; partisipasi dalam ekstrakurikuler; saya tidak ingin anak-anak diwajibkan pakai masker; saya ingin anak-anak wajib pakai masker; saya tidak ingin persyaratan wajib jaga jarak sosial; saya ingin persyaratan wajib jarak sosial, dan; Lainnya" .). Jawaban yang mendukung faktor diberi kode 1 dan tidak mendukung faktor diberi kode 0 dalam analisis regresi logistik 
polinomial. Kelompok rujukan yang dibandingkan dengan model instruksional tradisional, tatap muka, dan hybrid adalah guru yang memilih instruksi virtual sepenuhnya. Analisis dilakukan secara terpisah untuk guru siswa SD, SMP dan SMA.

\section{Hasil}

Di antara 100 guru, 52\% mendukung pilihan untuk format instruksi pembelajaran tradisional tatap muka di sekolah, 18\% mendukung pilihan untuk format instruksi pembelajaran sepenuhnya hybrid virtual untuk awal tahun akademik 2020 hingga 2021 dan 30\% mendukung pilihan untuk format instruksi pembelajaran di sekolah dan pengajaran hybrid virtual yang terjadwal. Uji Chi-square secara statistik sangat signifikan $(\mathrm{p}<0,01)$ antara pilihan guru SD dan SMP untuk format instruksi untuk awal tahun ajaran 2020 hingga 2021. Guru SMP (33,6\%) lebih mendukung pilihan format pembelajaran di sekolah dan pengajaran hybrid virtual yang terjadwal dibandingkan dengan guru SD (26,3\%). Guru SMP (50,5\%) lebih kecil kemungkinan untuk mendukung pilihan format pengajaran tatap muka tradisional dibandingkan dengan guru SD $(55,2 \%)$. Hasil analisis regresi logistik polinomial menunjukkan kekhawatiran tentang kesehatan/ keselamatan anak berhubungan kuat dengan pilihan guru pada format instruksi ( $\mathrm{p}<.001$ ), baik pada guru SD, SMP maupun SMA. Pada guru SD rasio ganjil dan interval kepercayaan 95\% lebih kuat dari guru SMP, dan menyusul pada guru SMA.

\section{Pembahasan}

Tujuan penelitian adalah untuk menilai pilihan guru pada pembelajaran di sekolah versus virtual di rumah dan faktor-faktor yang terkait dengan pilihan tersebut. Sedikit lebih dari setengah guru dalam sampel penelitian mendukung pilihan pada format pengajaran tradisional tatap muka di sekolah. Ada perbedaan sistematis dalam pilihan guru berdasarkan tingkat sekolah. Guru SMP dan SMA lebih mendukung pilihan format pembelajaran di sekolah dan pengajaran hybrid virtual yang terjadwal dan tidak mendukung pilihan format pembelajaran tradisional tatap muka dibandingkan dengan guru SD. Terlepas dari tingkat sekolah, kekhawatiran tentang kesehatan dan keselamatan anak-anak dan siswa remaja adalah faktor yang paling kuat terkait dengan pilihan guru pada pembelajaran di sekolah versus pembelajaran virtual di rumah.

Temuan ini menyoroti pentingnya rencana pembukaan kembali sekolah yang menawarkan pilihan virtual dan menangani kekhawatiran guru tentang kesehatan dan 
keselamatan anak di tengah pandemi Covid-19. Pilihan-pilihan ini dapat berkisar dari model instruksional di rumah yang sepenuhnya virtual hingga model hybrid yang mencakup komponen virtual dan tatap muka. Salah satu faktor yang harus dipertimbangkan sekolah ketika merancang rencana pembukaan kembali yang menyertakan komponen virtual adalah akses siswa ke komputer dan koneksi internet yang andal. Guru sekolah dapat menyediakan komputer tablet untuk setiap siswa selama tahun akademik 2020 hingga 2021. Sekolah juga dianjurkan memiliki akses ke program perangkat lunak yang memfasilitasi pembelajaran online dan dukungan teknologi yang komprehensif. Sekolah yang tidak memiliki sumber daya teknologi yang diperlukan untuk pembelajaran virtual mungkin dapat mengajukan permohonan hibah dan sumber pendanaan lain untuk membeli komputer dan program perangkat lunak. Ketika siswa tidak memiliki akses ke koneksi internet yang dapat diandalkan, sekolah harus menentukan apakah model pembelajaran virtual di rumah benar-benar sesuai. Sekolah yang berencana membuat program model pembelajaran virtual pada tahun ajaran baru dapat secara langsung menanyakan kepada keluarga tentang akses ke koneksi internet yang dapat diandalkan. Sekolah juga dapat mempertimbangkan untuk meminta guru menandatangani perjanjian yang mengakui perlunya memelihara sumber internet yang andal, sementara siswa berpartisipasi dalam pembelajaran online.

Menawarkan pilihan program pembelajaran online virtual sangat penting bagi sekolahsekolah di daerah yang mengalami tingkat Covid-19 yang tinggi. Meskipun konsensus umum di antara para profesional medis adalah bahwa Covid-19 biasanya tidak berdampak pada kesehatan anak-anak dan remaja separah kelompok usia lainnya, Covid-19 telah dikaitkan dengan kondisi langka yang berpotensi mengancam jiwa pada anak-anak yang disebut multisystem inflammatory syndrome. ${ }^{20}$ Jika anak-anak memiliki kondisi kesehatan lain yang mendasari, anak-anak mungkin memiliki risiko terbesar dalam perkembangan multisystem inflammatory syndrome sebagai respons terhadap Covid-19. ${ }^{21}$

Konsisten dengan temuan ini, guru dalam penelitian ini lebih mendukung kekhawatiran tentang kesehatan dan keselamatan anak-anak jika memiliki anak dengan kebutuhan perawatan kesehatan khusus (misalnya, asma, bronchitis, paru-paru dan gangguan saluran pernafasan

20 Shulman, S. T. (2020). Pediatric coronavirus disease-2019-associated multisystem inflammatory syndrome.Pediatr Infect Dis Journal, 9, 3, 285-286.

${ }^{21}$ US Centers for Disease Control and Prevention. Coronavirus Disease 2019 (Covid-19). (2020). Atlanta, GA: US Centers for Disease Control and Prevention. https://www.cdc .gov/coronavirus/2019-ncov/need-extraprecautions/people- with-medical-conditions.html. Diakses 20 November 2020. 
lainnya). Sekolah membutuhkan kehadiran perawat sekolah yang berperan penting dalam mengelola kebutuhan perawatan kesehatan siswa di sekolah. ${ }^{22}$ Kemungkinan perawat sekolah akan diminta untuk mengambil tanggung jawab yang lebih besar ketika sekolah dibuka kembali pada tahun ajaran baru. Bagian dari tanggung jawab yang diberikan pada perawat sekolah mungkin melibatkan inisiatif khusus untuk melindungi siswa dengan kondisi kesehatan yang mendasari dan menghadiri kelas secara langsung. Sekolah harus mempertimbangkan cara-cara untuk mendukung perawat sekolah saat sekolah dibuka kembali, termasuk mempekerjakan staf pendukung tambahan dan menyediakan perawat dengan persediaan dan peralatan yang diperlukan untuk menjaga kesehatan siswa di sekolah.

Salah satu tantangan dalam membuat rencana pembukaan kembali sekolah yang mempromosikan keselamatan dan kesehatan di antara siswa adalah memiliki harapan yang sesuai dengan perkembangan. Seperti yang diakui oleh banyak guru dalam penelitian ini, mengharapkan siswa usia sekolah dasar untuk dapat memakai masker dalam waktu yang lama atau jarak sosial yang sesuai dari teman sebaya tidaklah sesuai perkembangan. Banyak guru berkomentar prihatin tentang praktik jaga jarak sosial (misalnya, tidak ada jam istirahat, tidak ada makan siang di kantin) atau pemakaian masker yang diterapkan di sekolah, karena hal ini berpotensi menimbulkan efek yang merusak kesehatan mental anak-anak. Penting bagi sekolah yang membuka kembali untuk pengajaran secara langsung pada tahun ajaran baru untuk mengatasi kekhawatiran orang tua tentang jarak sosial yang sesuai dengan perkembangan dan pemakaian masker. Misalnya, sekolah harus memberikan informasi terperinci kepada guru tentang tindakan pencegahan yang akan diterapkan di lingkungan sekolah. ${ }^{23}$

Informasi yang diberikan kepada guru harus membahas praktik jaga jarak sosial tertentu yang akan diterapkan, data yang mendukung praktik ini, siapa di sekolah yang akan bertanggung jawab untuk menegakkan praktik tersebut, dan konsekuensi apa (jika ada) yang akan dihadapi siswa jika melakukannya, tidak mematuhi pedoman. Informasi ini juga harus membahas situasi di mana pengecualian akan dibuat seperti tidak memerlukan penggunaan masker saat siswa mengalami kesulitan bernapas atau tidak dapat melepas masker tanpa bantuan. Mengingat bahwa inisiatif seperti mengenakan masker telah menimbulkan beberapa kontroversi selama pandemi

${ }^{22}$ Nordheim, S. (2019). Hands-only cardiopulmonary resuscitation training in schools: impact of legislation on the future of school nurses. Journal of School Health, 89, 10, 860-862.

${ }^{23}$ Perez, A., Rodriguez, T., Lopez, M., Continente, X., \& Nebot, M. (2016). Adoption of preventive measures and attitudes toward the H1N1 influenza pandemic in schools. Journal of School Health, 86, 7, 534-542. 
Covid-19, akan sangat berharga bagi sekolah yang menerapkan tindakan pencegahan keselamatan untuk instruksi secara langsung dengan memberi orang tua kesempatan mengajukan pertanyaan dan menyampaikan kekhawatiran. Bagi sekolah yang memang membutuhkan masker atau kain penutup muka, barang-barang ini harus disediakan bagi siswa untuk memfasilitasi kepatuhan terhadap kewaspadaan sekolah. Meskipun studi ini tidak secara eksplisit menilai kekhawatiran tentang kesehatan dan keselamatan staf sekolah dan guru, ini adalah masalah lain yang harus ditangani sekolah saat mengembangkan rencana pembukaan kembali sekolah di tahun ajaran baru dengan "new normal". Sekolah harusjuga mempertimbangkan untuk menawarkan guru dan staf yang termasuk dalam kategori berisiko tinggi dengan prioritas memberikan pengajaran di rumah yang sepenuhnya virtual. Selain itu, guru yang memiliki anak kecil atau anak usia sekolah yang tidak dapat menitipkan di penitipan anak atau sekolah karena penutupan Covid-19, harus juga dipertimbangkan sebagai prioritas untuk menyampaikan pembelajaran dengan instruksi online.

\section{Kesimpulan}

Guru sekolah menengah pertama dan sekolah menengah atas lebih mendukung pemilihan format pembelajaran hybrid di sekolah dan pengajaran hybrid virtual terjadwal dan tidak mendukung pemilihan format pembelajaran tradisional tatap muka di sekolah. Sementara itu, guru sekolah dasar lebih mendukung format pembelajaran tradisional. Terlepas dari tingkat sekolah, kekhawatiran tentang kesehatan dan keselamatan anak adalah faktor yang paling kuat berkorelasi dengan preferensi guru untuk pembelajaran di sekolah versus pembelajaran virtual di rumah. Data ini menyoroti pentingnya rencana untuk membuka kembali sekolah yang menawarkan pilihan virtual dan mengatasi kekhawatiran guru tentang kesehatan dan keselamatan anak di tengah pandemi Covid-19.

\section{Daftar Referensi}

American Academy of Pediatrics (2020). Covid-19 planning considerations: Guidance for school re-entry website. Itasca, IL: American Academy of Pediatrics. https://services.aap .org/en/pages/2019-novel-coronavirus-covid-19-infections/ clinical-guidance/covid-19planning-considerations-return-to-in-person-education-in-schools/. Diakses 20 November 2020.

Belawati, t. et al. (Ed.). Pendidikan Terbuka dan Jarak Jauh. Jakarta: Universitas Terbuka. Diakses 20 November 2020. 
Chusna, P. A., \& Utami, A. D. M. (2020). Dampak Pandemi Covid-19 terhadap Peran Orang Tua dan Guru dalam Meningkatkan Kualitas Pembelajaran Daring Anak Usia Sekolah Dasar. Premiere, 2, 1, 11- 30 .

Coronavirus Disease 2019 (COVID-19). Centers for Disease Control and Prevention. Diakses 20 November 2020..

Coronavirus Update: Masks And Temperature Checks In Hong Kong. Nevada Public Radio.

COVID-19 Educational Disruption and Response. UNESCO. Diakses 20 November 2020.

Deerwester, J., \& Gilbertson, D. Coronavirus: US says 'do not travel' to Wuhan, China, as airlines issue waivers, add safeguards. USA Today. Diakses 20 November 2020.

Gorbalenya, A. E. (11 Februari 2020). Severe acute respiratory syndrome-related coronavirus The species and its viruses, a statement of the Coronavirus Study Group. Diakses 20 November 2020.

Julaeha, S. Virtual Learning: Pemanfaatan Teknologi Informasi DDan Komunikasi Untuk Meningkatkan Kualitas Pembelajaran. Universitas Terbuka. file:///C:/Users/12/Downloads/6868-17770-1-SM\%20(1).pdf . Diakses 20 November 2020.

Marsh, S. (23 February 2020). Four cruise ship passengers test positive in UK - as it happened. The Guardian. ISSN 0261-3077. Diakses 20 November 2020.

Nikel, D. Denmark Closes Border To All International Tourists For One Month. Forbes. 13 March 2020. Diakses 20 November 2020.

Nordheim, S. (2019). Hands-only cardiopulmonary resuscitation training in schools: impact of legislation on the future of school nurses. Journal of School Health, 89, 10, 860-862.

Perez, A., Rodriguez, T., Lopez, M., Continente, X., \& Nebot, M. (2016). Adoption of preventive measures and attitudes toward the H1N1 influenza pandemic in schools. Journal of School Health, 86, 7, 534-542.

Q\&A on coronaviruses. World Health Organization. Diakses 20 November 2020.

Rothan, H. A., \& Byrareddy, S. N. (February 2020). The epidemiology and pathogenesis of coronavirus disease (COVID-19) outbreak. Journal of Autoimmunity: 102433. doi:10.1016/j.jaut.2020.102433 Diakses 20 November 2020.

Shulman, S. T. (2020). Pediatric coronavirus disease-2019-associated multisystem inflammatory syndrome.Pediatr Infect Dis Journal, 9, 3, 285-286.

SKB Nomor 01/KB/2020; Nomor 516 Tahun 2020; Nomor HK.03.01/Menkes/363/2020; Nomor 440-882 Tahun 2020 Tentang Panduan Penyelenggaraan Pembelajaran pada Tahun 
Ajaran 2020/2021 dan Tahun Akademik 2020/2021 di Masa Pandemi Corona Virus Disease 2019 (Covid-19). Diakses 20 November 2020.

Symptoms of Novel Coronavirus (2019-nCoV). US Centers for Disease Control and Prevention. Diakses 20 November 2020.

US Centers for Disease Control and Prevention. Coronavirus Disease 2019 (Covid-19). (2020). Atlanta, GA: US Centers for Disease Control and Prevention. https://www.cdc .gov/coronavirus/2019-ncov/need-extra-precautions/people-with-medical-onditions.html. Diakses 20 November 2020.

WHO Director-General's opening remarks at the media briefing on COVID-19 - 11 March 2020. www.who.int. Diakses 20 November 2020. 